\title{
Adaptation of Lambadi Embroidery to Embellish Contemporary Apparel and Accessories
}

\author{
Godi Sindhu* and Shahnaz Jahan \\ Department of Clothing and Textiles, College of Home Science, G.B. Pant University of \\ Agriculture and Technology, Pantnagar, India \\ *Corresponding author
}

\section{A B S T R A C T}

\section{Keywords \\ Lambadi, Costumes, \\ Motifs, Corel draw, \\ Adaptation, \\ Contemporary, Apparel, \\ Accessories \\ Article Info \\ Accepted: \\ 04 October 2018 \\ Available Online: \\ 10 November 2018}

The former study was conducted in Andhra Pradesh to explore various traditional costumes and textiles used by Lambadi and Koya tribes. Documentation was prepared on traditional costumes and textiles and as a part of the study, an interesting feature of Lambadi costumes; embroidery was taken to adapt the motifs on contemporary apparel and accessories. Therefore motifs created with different techniques such as embroidery, combination of embroidery and applique, mirror work and bead work were collected from their costumes and the collected motifs were adapted for application on college going students contemporary apparel and accessories.

\section{Introduction}

Embroidery is an embellishment on existing fabric with threads, accessories and with other decorative materials such as fish skin, teeth, bone, feathers, horns shell, beetle wings, tassels, beads, coins, buttons, metal mirror etc, (Paine, 1990). Bright colors and random designs are the most unique features of Lambadi embroidery. All over patterns are created to cover the quilted base of the fabric, whereas, few geometric patterns like squares, circles, rectangles, rhombus patterns were also created. The Lambadi embroidery is done with colorful cotton threads and embellishments like coins, mirrors, beads, shells etc, Applique is an another form of technique which was used by Lambadis to create patterns such as triangles, flowers and other geometrical patterns (Kohli, 2014).

\section{Materials and Methods}

The present study was conducted in G.B.P.U.A.T, Pantnagar. Total 32 motifs were selected from the apparel sources of Lambadi women and divided into 4 categories namely embroidery, combination of embroidery and appliqué, mirror work and bead designs. The collected motifs were modified with the help of CorelDraw X4 software and evaluated on five point rating scale by 30 experts including 
faculty, Ph.D. and M.Sc. students from the department of Clothing and Textiles, College of Home science, Pantnagar. Twelve motifs, i.e., three from each category which got highest weighted mean score were selected for the design arrangement on the products. The weighted mean scores of adapted motifs are given in Table 1 . The selected motifs were evaluated for suitable embroidery stitches. After the finalization of motifs and stitches, the contemporary apparel kurti, top, long skirt, palazzo and the accessories stole and hand bag were planned for the college going students. Following the planning of products, the selected motifs were arranged on planned products and evaluated by the experts. The selected arrangements were prepared and later on the evaluation of consumer acceptability for prepared articles was done on the basis of design parameters such as suitability of motif, placement of motif on the garment, combination of motifs, suitability of embroidery stitches, fineness of embroidery, color combination and overall appearance of the garment.

\section{Results and Discussion}

The collected motifs were modified by simplification with the help of Corel Draw X4 software. The modified motifs were evaluated by a panel of judges on the basis of suitability of motifs to be embroidered on contemporary apparel and accessories such as kurti, top, long skirt, palazzo, stole and hand bag. The motifs from the four categories which got the highest weighted mean score were selected for the further study as given in Table 1 .

After finalization of motifs through evaluation, the next evaluation was done to select the embroidery stitches for the selected motifs of respective category. The judges were provided with the selected motifs along with the suitable embroidery stitches. Each motif was given with option of three types of stitches for evaluation. The stitches for each motif were visually evaluated and order of preference was given by the same panel of judges. The embroidery stitch which got the highest weighted mean score for each motif was selected for further study. The selected motifs along with their selected embroidery stitches were given from Table 2 to 5. After the finalization of motifs and stitches, the contemporary apparel namely kurti, top, long skirt, palazzo and accessories namely stole and hand bag, total six products were planned to prepare for college going students.

Followed by the planning of contemporary apparel and accessories, each product was arranged with four categories of selected motifs that were embroidery, combination of embroidery and appliqué, bead and mirror motifs in four different styles. Total twenty four arrangements were prepared (6 products $\mathrm{X} 4$ styles) as given from Figure 1 to 6 . The design arrangements were visually evaluated for order of preference by the same panel of judges on the basis of suitability of motif arrangement on the product and overall appearance. The design arrangement which got the highest weighted mean score was selected for each product as given in Table 6 . Finally, the products were prepared for the selected design arrangements and the prepared products are shown from Figure 7 to 9 .

The embroidered products were assessed for consumer acceptability by thirty consumers including $15 \mathrm{Ph} . \mathrm{D}$. students and 15 M.Sc. students from the different departments of College of Home Science and College of Agriculture. All the developed products got high consumer acceptability and aesthetically, fineness of embroidery was valued best for all the prepared products. The parameter suitability and placement of motifs on the garment valued least in case of top and long skirt and the color combination valued least in case of kurti, palazzo, stole and hand bag. 
Int.J.Curr.Microbiol.App.Sci (2018) 7(11): 183-194

Table.1 Weighted mean scores of adapted motifs $(n=30)$

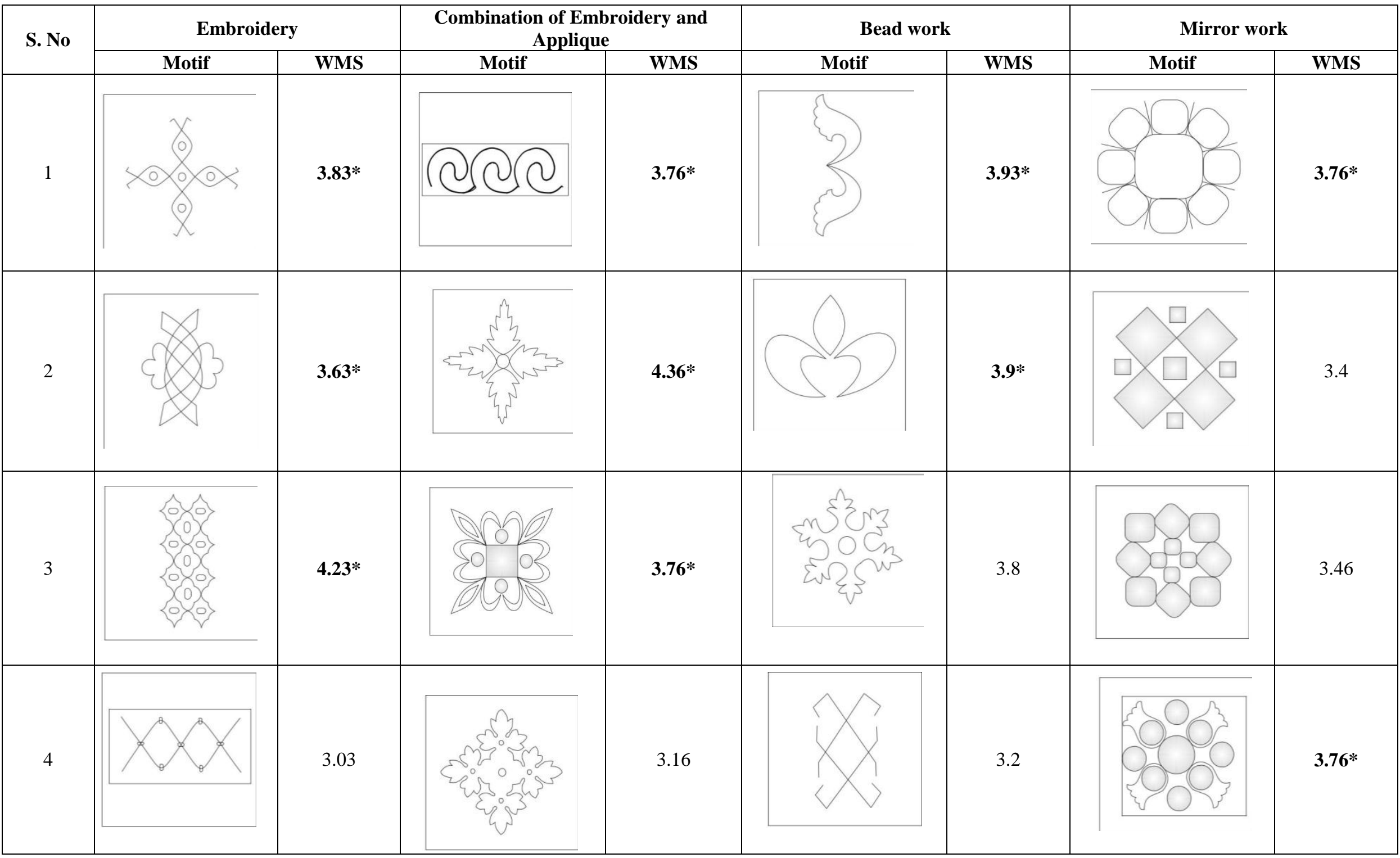


Int.J.Curr.Microbiol.App.Sci (2018) 7(11): 183-194

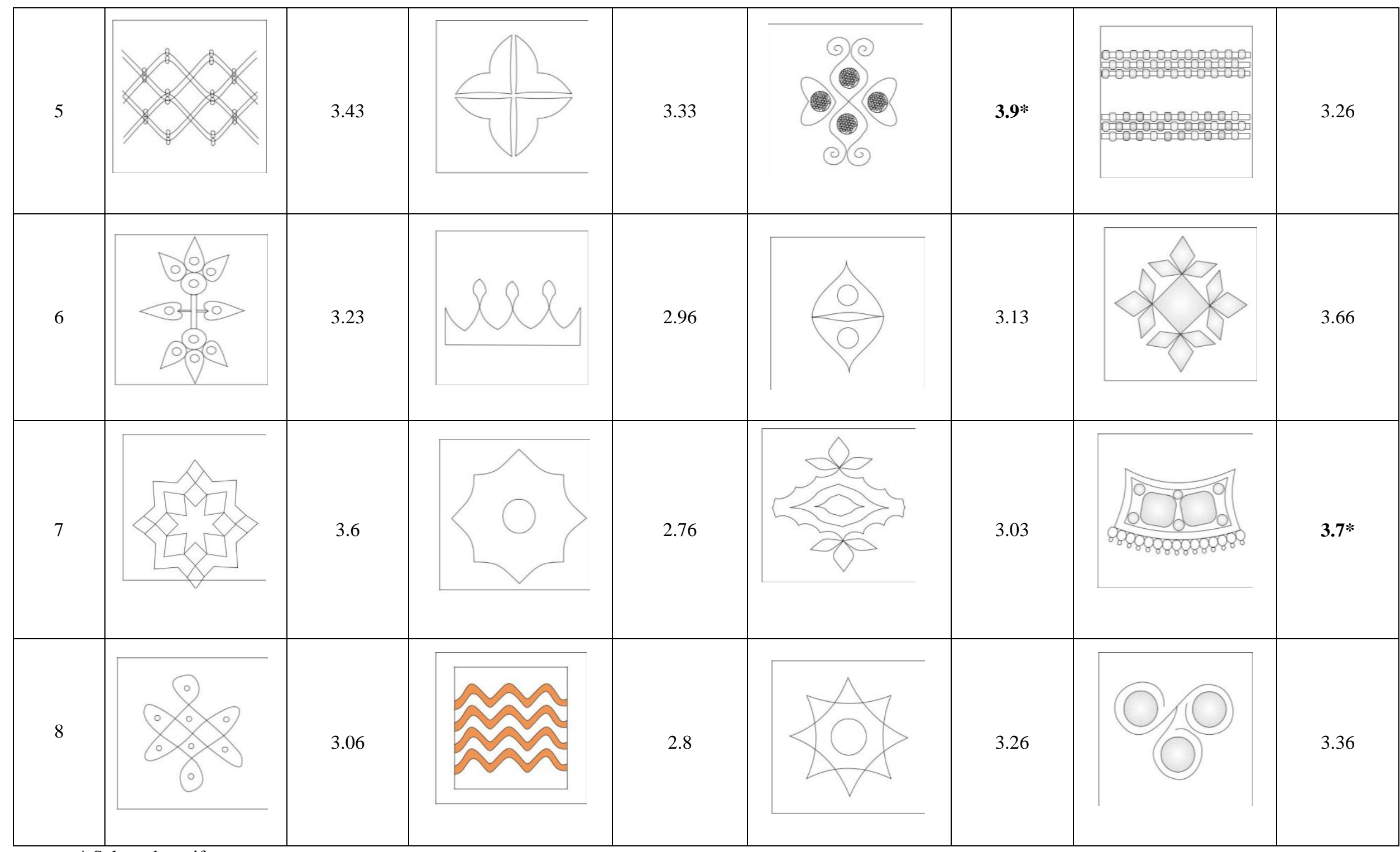

* Selected motifs 
Table.2 Weighted mean scores of selected stitches for embroidery motifs

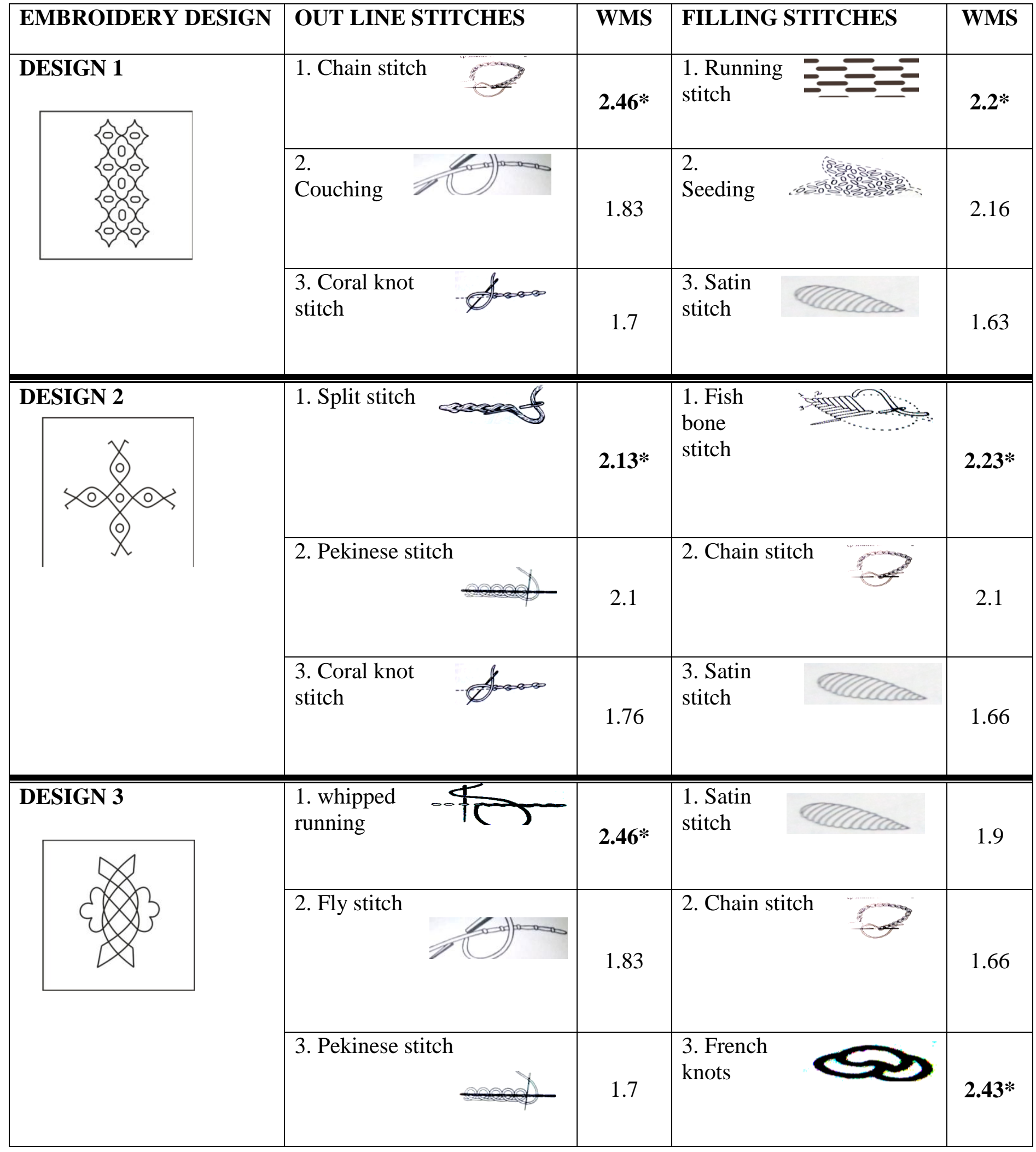


Table.3 Weighted mean scores of selected stitches for combination of embroidery and Appliqué designs

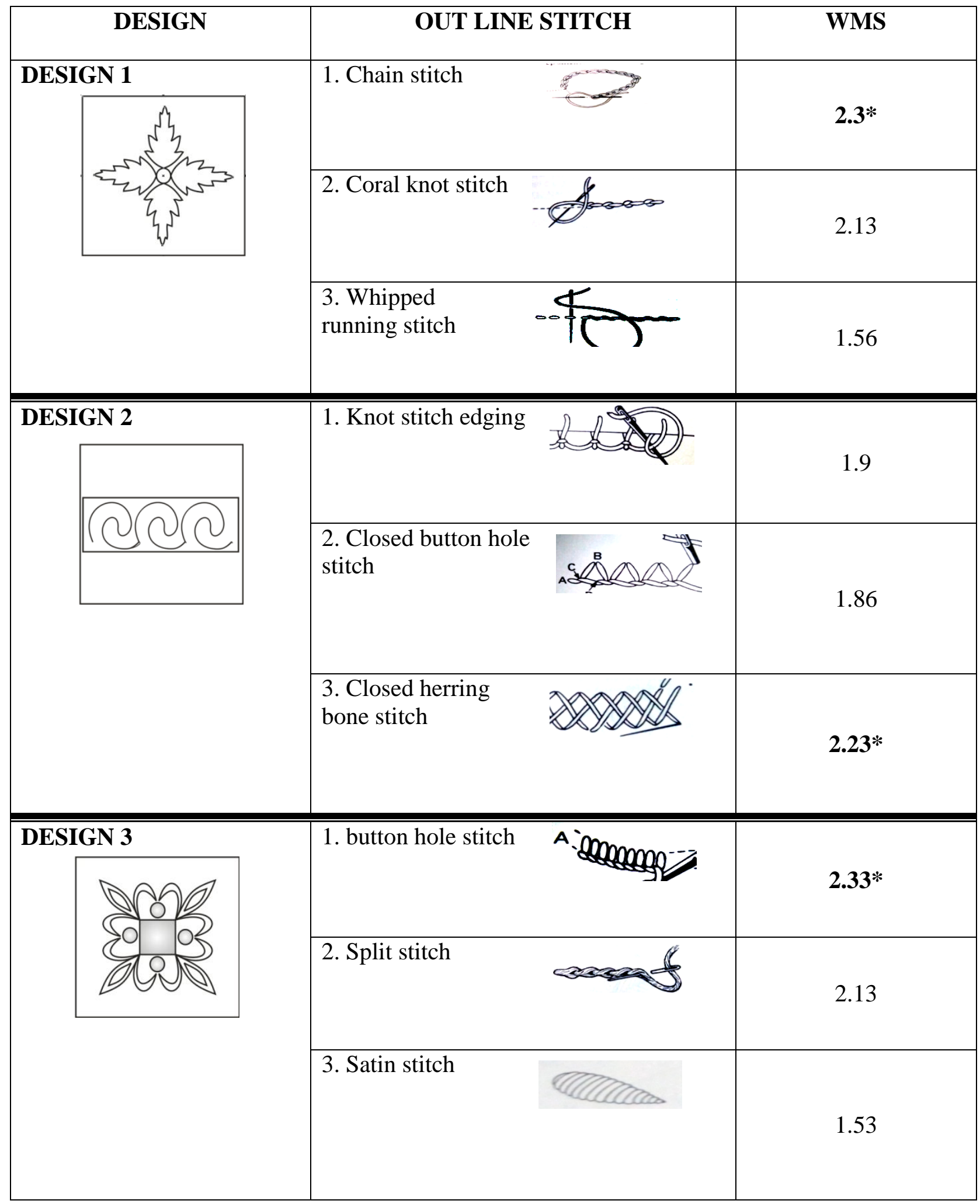


Table.4 Weighted mean scores of selected stitches for bead designs

\begin{tabular}{|c|c|c|c|}
\hline DESIGN & STIT & CHES & WMS \\
\hline DESIGN 1 & $\begin{array}{l}\text { 1. Single line of } \\
\text { with back stitch }\end{array}$ & erecuerese beads & \\
\hline & $\begin{array}{l}\text { 2. single line beads } \\
\text { alternate French knots }\end{array}$ & teseces with & $2.26 *$ \\
\hline & 3. Beads with chain & stitch & 1.9 \\
\hline DESIGN 2 & 1. Beads with double & Thenteloy line & \\
\hline & $\begin{array}{l}\text { 2. single line beads } \\
\text { alternate knots }\end{array}$ & dwoxerel with & 2.0 \\
\hline & 3. Beads with fly & Ititch & $2.06 *$ \\
\hline$\overline{\text { DESIGN } 3}$ & 1. Single line of beads & & \\
\hline ๑) & & & 2.03 \\
\hline & $\begin{array}{l}\text { 2. single line beads } \\
\text { with alternate French } \\
\text { knots }\end{array}$ & aneserel & $2.4 *$ \\
\hline & $\begin{array}{l}\text { 3. Beads with stem } \\
\text { stitch }\end{array}$ & Kentsing & 1.56 \\
\hline
\end{tabular}


Table.5 Weighted mean scores of selected stitches for mirror designs

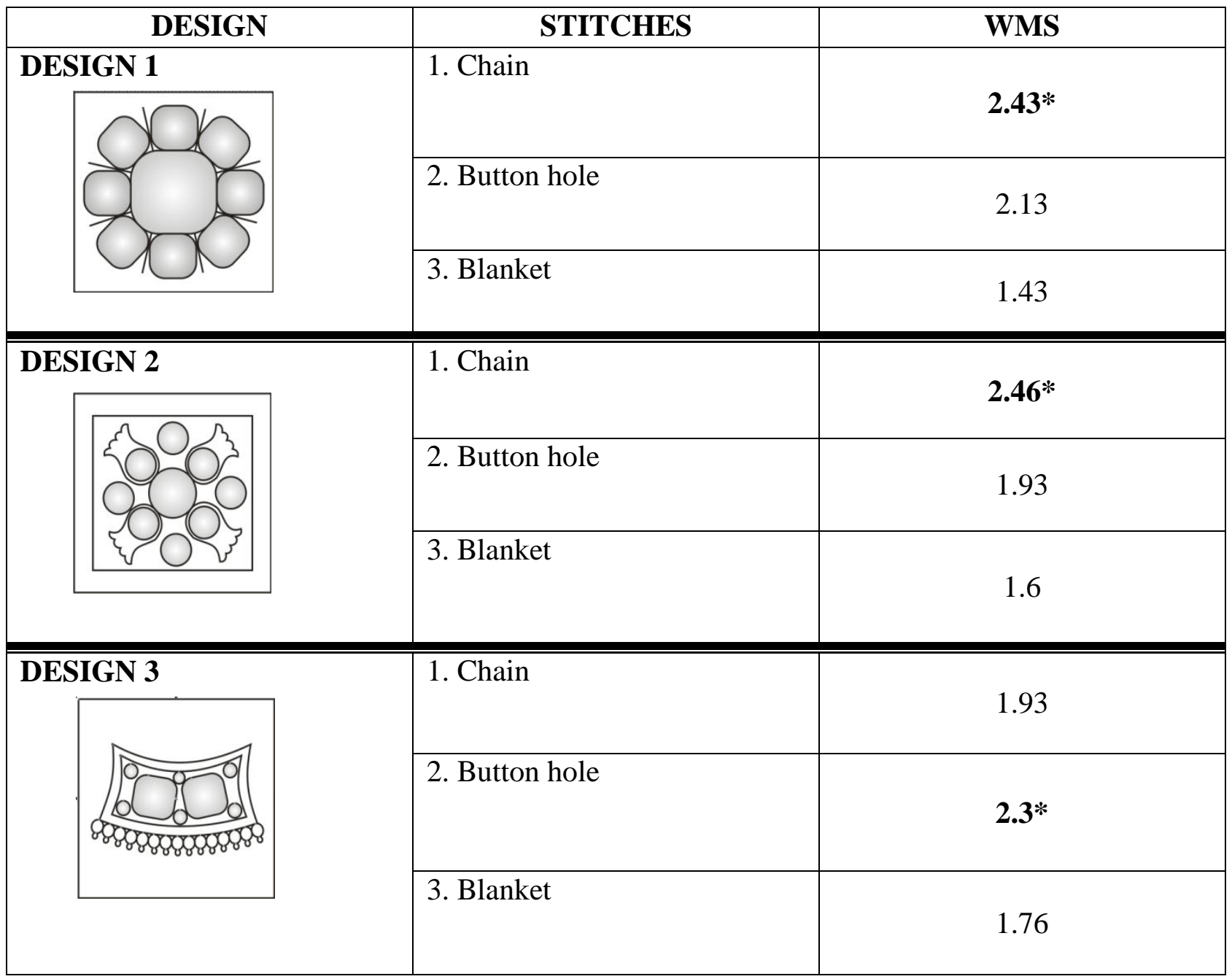

*Selected stitches

Table.6 Weighted mean scores of prepared design arrangements $(n=30)$

\begin{tabular}{|c|c|c|c|c|c|}
\hline Garment & $\begin{array}{c}\text { Name of the } \\
\text { Garment }\end{array}$ & $\begin{array}{c}\text { Arrangement } \\
1\end{array}$ & $\begin{array}{c}\text { Arrangement } \\
2\end{array}$ & $\begin{array}{c}\text { Arrangement } \\
\mathbf{3}\end{array}$ & Arrangement 4 \\
\hline \multirow{2}{*}{$\begin{array}{l}\text { Upper } \\
\text { Garments }\end{array}$} & Kurti & $2.8 *$ & 2.43 & 2.4 & 2.36 \\
\hline & Top & $3.0 *$ & 2.13 & 2.36 & 2.5 \\
\hline \multirow{2}{*}{$\begin{array}{l}\text { Lower } \\
\text { Garments }\end{array}$} & Long Skirt & $3.2 *$ & 2.23 & 2.36 & 2.2 \\
\hline & Palazzo & 2.0 & 2.9 & $3.13 *$ & 1.96 \\
\hline \multirow[t]{2}{*}{ Accessories } & Stole & $3.0 *$ & 2.73 & 1.76 & 2.5 \\
\hline & Hand Bag & 2.43 & 2.73 & $2.96 *$ & 1.86 \\
\hline
\end{tabular}

*Selected design arrangements 
Table.7 Weighted mean scores of consumer acceptability for prepared products $(n=30)$

\begin{tabular}{|c|c|c|c|c|c|c|c|}
\hline \multirow{2}{*}{$\begin{array}{l}\text { S. } \\
\text { No }\end{array}$} & \multirow[t]{2}{*}{ Parameters } & \multicolumn{6}{|c|}{ Weighted Mean Scores } \\
\hline & & Kurti & Top & $\begin{array}{l}\text { Long } \\
\text { Skirt }\end{array}$ & Palazzo & Stole & $\begin{array}{c}\text { Hand } \\
\text { Bag }\end{array}$ \\
\hline 1 & $\begin{array}{l}\text { Combination of } \\
\text { motifs in the } \\
\text { arrangement }\end{array}$ & 4.4 & 4.63 & 4.73 & 4.86 & 4.5 & 4.7 \\
\hline 2 & $\begin{array}{l}\text { Suitability and } \\
\text { placement of } \\
\text { motifs on the } \\
\text { garment }\end{array}$ & 4.53 & 4.46 & 4.6 & 4.8 & 4.6 & 4.56 \\
\hline 3 & $\begin{array}{l}\text { Suitability of } \\
\text { embroidery } \\
\text { stitches }\end{array}$ & 4.73 & 4.76 & 4.86 & 4.96 & 4.76 & 4.63 \\
\hline 4 & $\begin{array}{l}\text { Fineness of } \\
\text { embroidery }\end{array}$ & $4.83 *$ & $4.93 *$ & $5.0 *$ & $5.0 *$ & $4.93 *$ & $4.96 *$ \\
\hline 5 & Color combination & 4.23 & 4.76 & 4.63 & 4.76 & 4.46 & 4.2 \\
\hline 6 & $\begin{array}{l}\text { Overall } \\
\text { appearance }\end{array}$ & 4.56 & 4.56 & 4.76 & 4.83 & 4.7 & 4.23 \\
\hline Ovi & all Preference $\left(\sum\right)$ & 4.54 & 4.68 & 4.76 & 4.86 & 4.65 & 4.54 \\
\hline
\end{tabular}

Table.8 Calculated cost of the embroidered products

\begin{tabular}{|c|c|c|}
\hline S. No & Item & Cost (₹) \\
\hline $\mathbf{1}$ & Kurti & $583 /-$ \\
\hline $\mathbf{2}$ & Top & $454 /-$ \\
\hline $\mathbf{3}$ & Long skirt & $995 /-$ \\
\hline $\mathbf{4}$ & Palazzo & $722 /-$ \\
\hline $\mathbf{5}$ & Stole & $367 /-$ \\
\hline $\mathbf{6}$ & Hand bag & $346 /-$ \\
\hline
\end{tabular}


Fig: 1. Prepared and selected design arrangement for Kurti
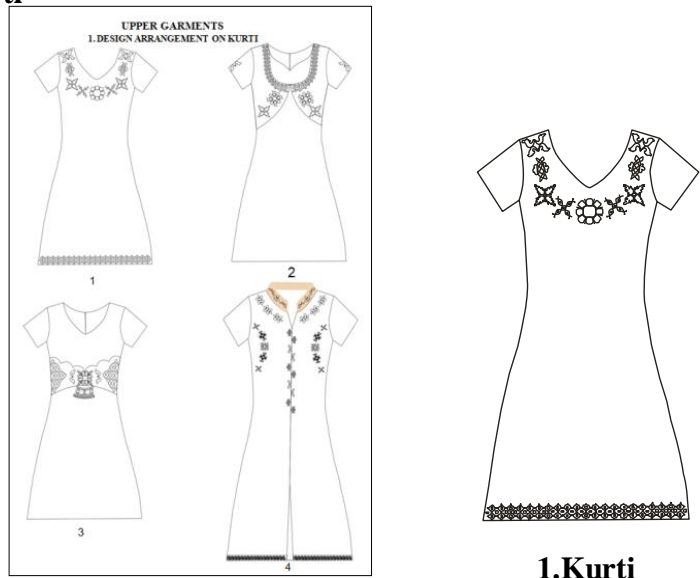

1.Kurti

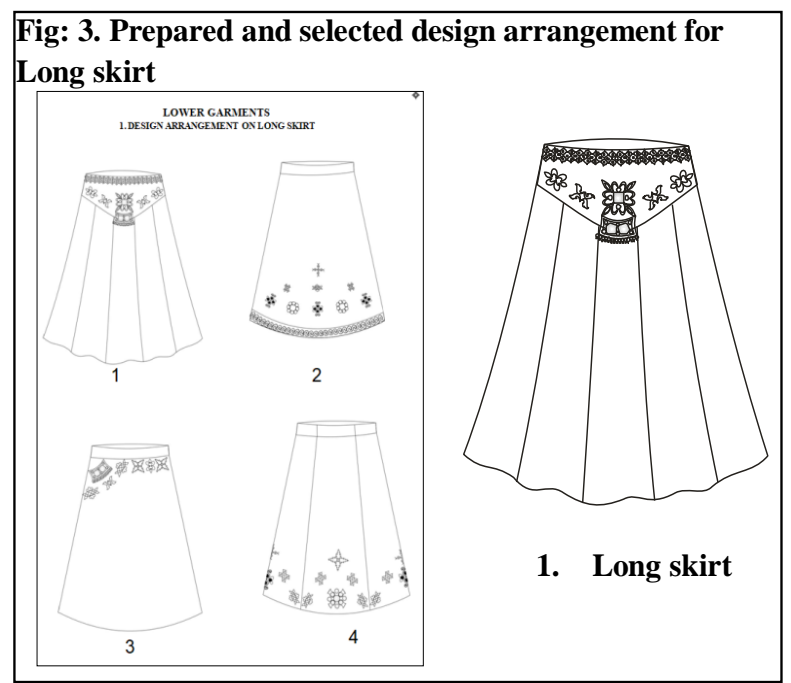

Fig: 5. Prepared and selected design arrangement for Stole
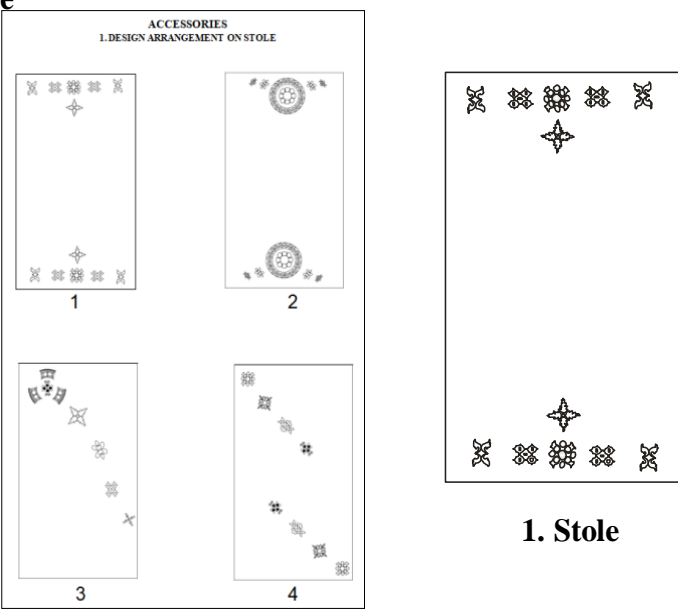

1. Stole
Fig: 2. Prepared and selected design arrangement for Top
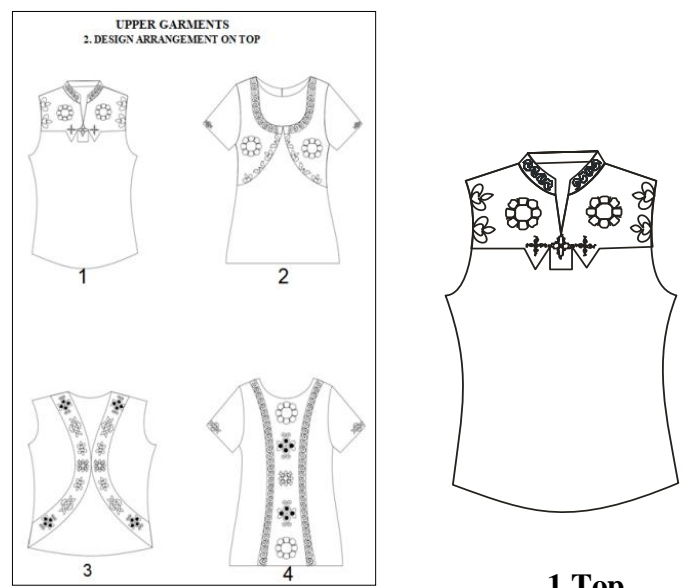

1.Top

Fig: 4. Prepared and selected design arrangement for Palazzo

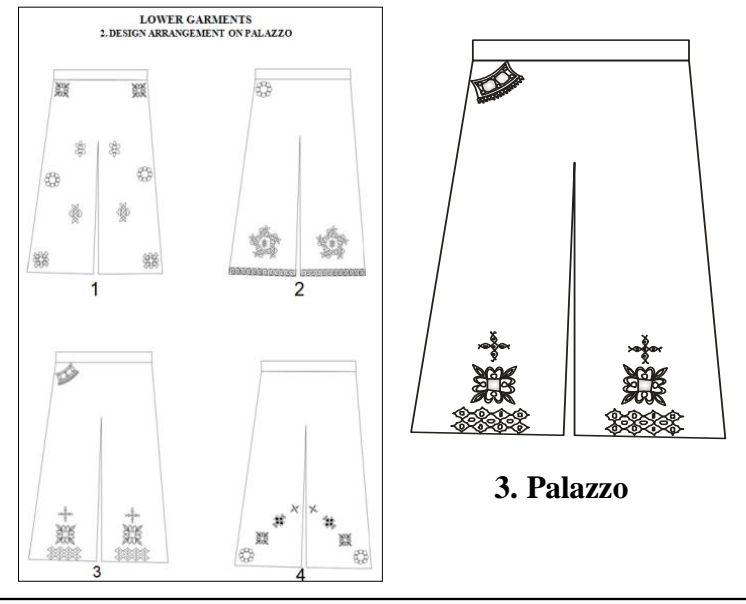

Fig: 6. Prepared and selected design arrangement for Hand Bag
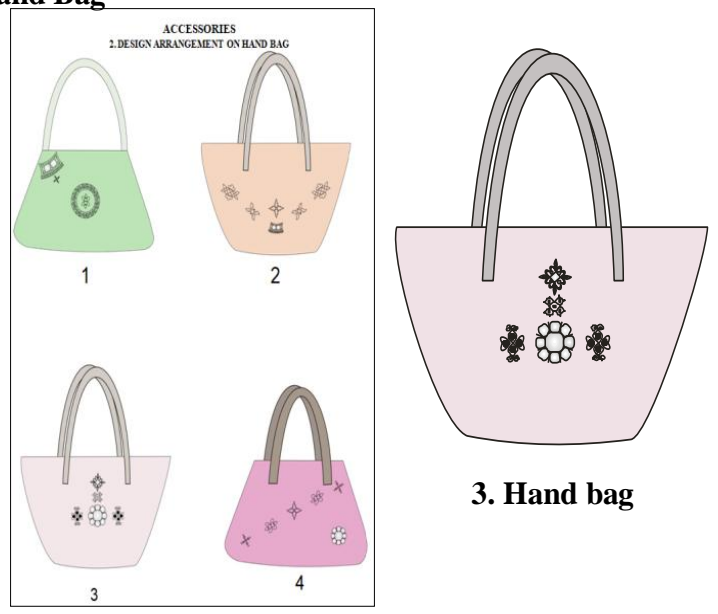

3. Hand bag 

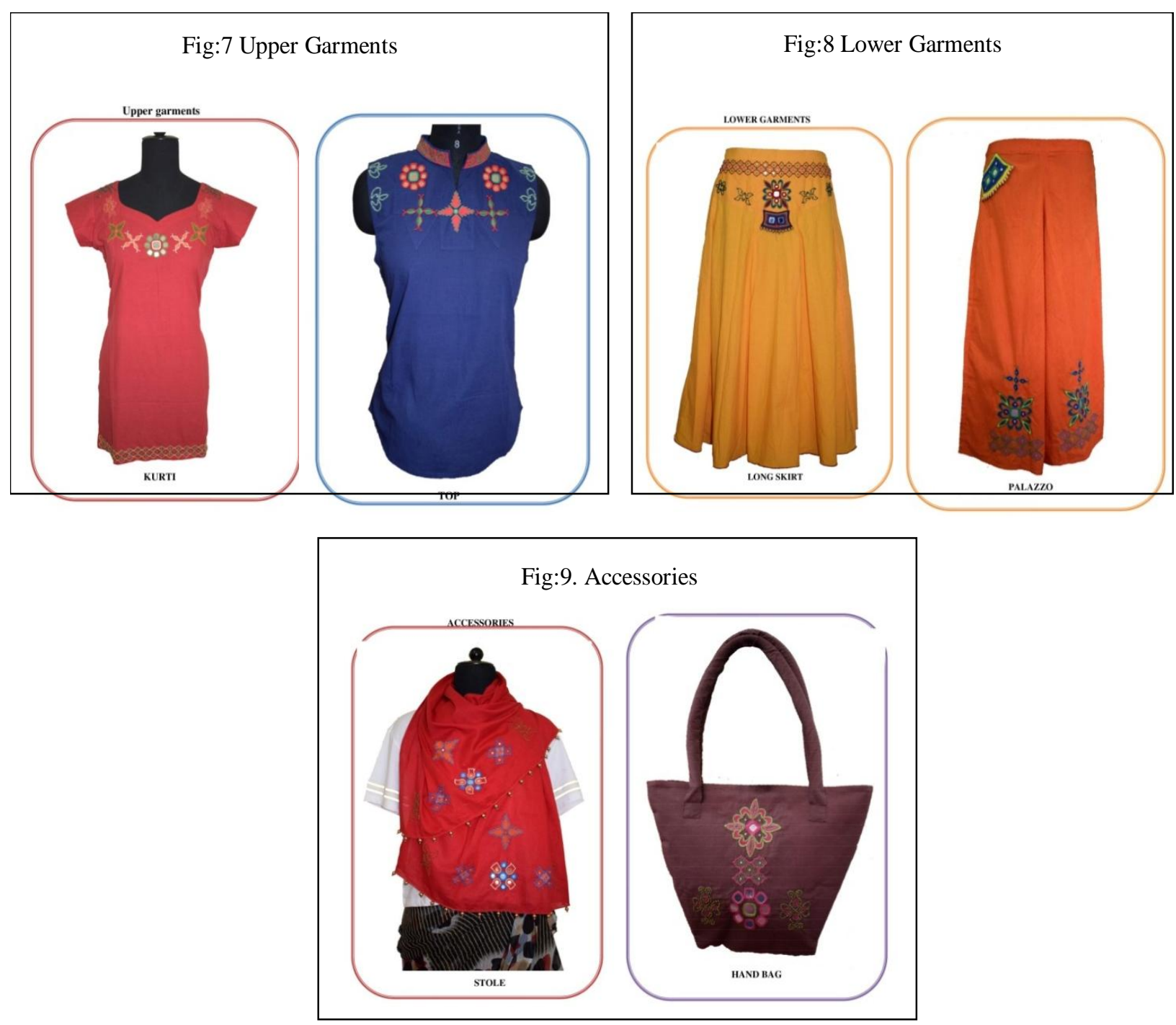

The respondents prefer the ladies top most on aesthetic appeal followed by kurti among the upper garments. In case of lower garments, palazzo was valued high followed by long skirt. In case of accessories, the embroidered stole was preferred most followed by hand bag. Among all the embroidered contemporary products the overall preference was given to palazzo with average 4.86 followed by long skirt (4.76), top (4.68), stole (4.65). The least and equally accepted products were kurti and hand bag with an average score of 4.54. Overall the lower garments were most preferred by the consumers followed by upper garments and accessories as shown in Table 7.
Calculated cost of the prepared contemporary embroidered products

The estimated cost of embroidered contemporary products were calculated on the basis of expenditure made on fabric, lining, embroidery threads, mirrors, beads, sequins and labour charges for stitching and hand embroidery. Among all the embroidered products, long skirt was costing high with Rs.995/-, whereas hand bag was costing lowest with Rs. 346/- as shown in Table 8.

There is always a desire for something new and creative in this fashion world. The clothing sector always demand for distinctive 
and fresh designs which leads to the opportunity to use adapted traditional motifs. Moreover, the designers can experiment these designs on the new area of development of designs.

All the prepared products were highly accepted and most of the respondents stated that they would certainly purchase these items if commercially available. The designs of tribal costume will also be useful for embellishing the other contemporary apparel and accessories, as the work done under the study has been appreciated by most of the consumers.

\section{References}

Kohli, K. 2014. Lambani Embroidery. The Banjaras. Fabrics, Fashion and Textiles. Retrieved on September 2017 from http://fft991.blogspot.in/2014/07/lamba ni-embroidery-banjaras.html.

Paine, S. 1990. Embroidered Textiles. $1^{\text {st }}$ Ed. Thames and Hudson. P. 165.

\section{How to cite this article:}

Godi Sindhu and Shahnaz Jahan. 2018. Adaptation of Lambadi Embroidery to Embellish Contemporary Apparel and Accessories. Int.J.Curr.Microbiol.App.Sci. 7(11): 183-194. doi: https://doi.org/10.20546/ijcmas.2018.711.022 